\title{
A NOTE ON THE THEIASMOS OF NICIAS IN THUCYDIDES
}

\author{
By Nanno Marinatos
}

Summary: Thucydides criticises Nicias for being too partial to divination (7.50.4). It is suggested here through the examination of the linguistic nuances of $\theta \varepsilon i \alpha \sigma u o ́ s$ and the

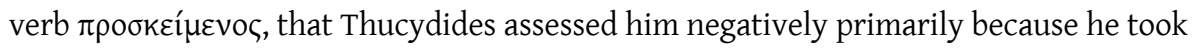
the side of the army-seers. Yet, this criticism ought not to be blown out of proportion. Thucydides' portrait differs significantly from Plutarch's who describes Nicias as a diffident man easily gripped by fear and addicted to prophecies. Consequently, Thucydides' criticism is a small parenthesis in his overall presentation of the Athenian general's career whose decisions were based on skill, rational criteria and experience (5.16.1).

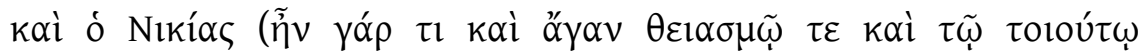

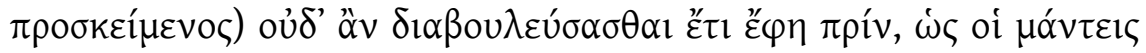

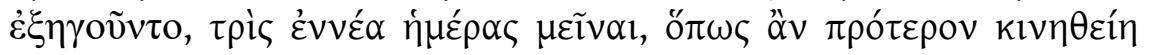
(Thuc. 7.50.4).

And Nicias (who was a bit too partial to theiasmos and the like), said he would not consider moving before they stayed still for three times nine days as the seers advised.

In this often-cited passage, Thucydides is clearly somewhat critical of $\mathrm{Ni}$ cias. The purpose of this note is to assess the nuances of his reproach by examining the broader context of the passage and the connection be-

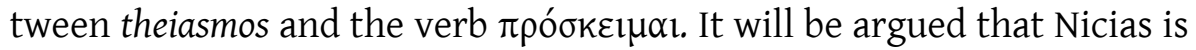
not criticized because of his personal theological beliefs but because of his softness towards the seers, the ones who undertook to interpret the divine will. 


\section{NARRATIVE CONTEXT}

The context is the highly dramatic situation of the Athenians after they suffered a major defeat before Syracuse. The generals have just taken the decision to withdraw and even Nicias, who on a previous occasion had expressed doubts about the wisdom of open departure, now agreed.

A few words ought to be said about Nicias' initial reluctance to withdraw openly. His reasoning was that when a besieging army decides to withdraw, it inevitably sends messages of weakness to the enemy and may invite pursuit. Thucydides writes:

Nicias, without denying the bad state of their affairs, was unwilling to avow their weakness $(\dot{\alpha} \sigma \theta \varepsilon v \tilde{\eta} \dot{\alpha} \pi \circ \delta \varepsilon 1 \kappa v v ́ v \alpha l)$, or to have it reported to the enemy that the Athenians in full council were openly voting for retreat; for in that case they would be much less likely to effect it when they wanted without discovery (7.48.1; trans. Crawley).

The historian additionally mentions that Nicias had accurate information that the Syracusans were running out of money and would capitulate soon (7.48.2). The generals' decision to hold out a bit longer was thus reasonable; however, as time went by and no offers of Syracusan surrender came forth, and as the condition of the Athenian army kept deteriorating, the generals unanimously made up their minds to depart in secrecy.

This much about the context. Then, Thucydides recites, something entirely unexpected occurred: "just as [the Athenians] were ready to sail

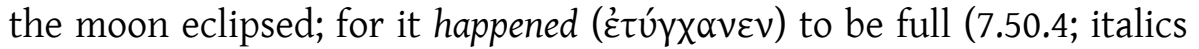
mine)." The incident of the eclipse is presented dramatically by the historian, as if it expressed an intrusion of the incalculable into the rational plans of man, a stroke of bad luck at a moment when escape still seemed possible. This lost opportunity has been amply pointed out by Hans Peter Stahl, Timothy Rood and others. ${ }^{1}$ To make things worse, the eclipse was viewed as ominous by the seers who accompanied the expedition and

1 As shown by Stahl 2003: 218-19. Rood 1998: 176 notes that 'the Athenian defeat could have been averted' had it not been for the delay after the eclipse. 
they advised that the army ought to stay immobile for 27 days. This advice must have been made in public because Thucydides writes that the

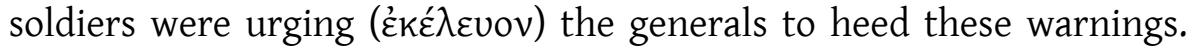
Next, comes the crucial passage where Thucydides remarks that Nicias was "a bit too partial to theiasmos and the like" and that he refused to move (7.50.4). In other words, Nicias agreed with the seers and the historian seems to be critical of this fact.

Plutarch took a more extreme view of the same event almost five centuries later when presenting his own version of Nicias' character. The latter's portrait does not match that of Thucydides since it clearly attributes the failure of the entire expedition to Nicias.

\section{PLUTARCH'S DESCRIPTION OF NICIAS' REACTION TO THE ECLIPSE}

Plutarch's account of the eclipse contains details which are not found in Thucydides and which may have been picked up from later authors who were far more distant from the events of 415 than Thucydides. ${ }^{2}$ As time went by, reality may have fused with legend and interpretation. Plutarch writes:

But just as everything was prepared for this and none of the enemy was on the watch, since they did not expect the move at all, there came an eclipse of the moon by night. This was a great terror to Nicias

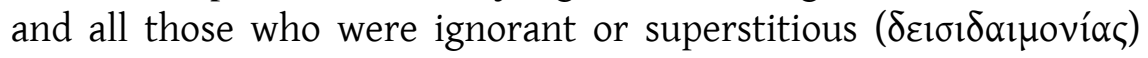
enough to quake at such a sight. The obscuration of the sun towards the end of the month was already understood, even by the common folk, as caused somehow or other by the moon; but what it was that the moon encountered, and how, being at the full, she should on a sudden lose her light and emit all sorts of colours, this was no easy thing to comprehend. Men thought it uncanny, - a sign sent from God in advance of diverse great calamities (Plu. Nic. 23.1; Perrin).

2 For a critical assessment of N.'s portrait and its divergence from that of Thuc. see Nikolaidis 1988: 328-29. 
Plutarch sketches a man who was not only superstitious but totally terrified as were also his men. This interpretation goes far beyond what Thucydides writes since the Athenian historian makes no mention of fear. ${ }^{3}$ Moreover, the latter's criticism is mitigated by the small particle 'somewhat' ( $\tau i)$, as first noted in 1975 by Stewart Irwin Oost, who went so far as to suggest that the phrasing presupposes that Thucydides accepted as reasonable "a degree of devotion to theiasmos and the like."

Another important difference between Thucydides and Plutarch is that the latter contrasts the alleged superstition of Nicias with the enlightened attitude of Pericles. In order fully to understand this comparison we must look at both biographies of Plutarch, his Pericles and his Nicias, and make a synthesis of his thoughts about enlightened attitudes and superstitious ones.

In his Pericles, Plutarch writes:

These were not the only advantages Pericles had of his association with Anaxagoras. It appears that he was also lifted by him above su-

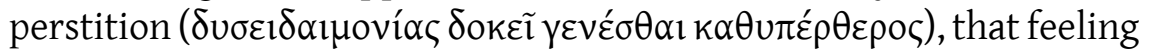
which is produced by amazement at what happens in regions above us" (Plu. Per. 6; trans. Perrin).

Anaxagoras appears also in the Nicias in the context of the moon eclipse which supposedly had terrified Nicias.

The fist man to put in writing the clearest and boldest of all doctrines about the changing phases of the moon was Anaxagoras. But he was no ancient authority, nor was his doctrine in high repute. It was still under a seal of secrecy, and made its way slowly among a few only, who received it with a certain caution rather with implicit confidence ... Anaxagoras was with difficulty rescued from imprisonment by Pericles ... (Plu. Nic. 23.2-3; trans. Perrin).

Plutarch was obviously impressed by Anaxagoras' scientifically based doctrines and used them as a criterion to judge the level of rationalism

3 Nikolaidis 1988: 328-29; Pelling 1992; 1999.

4 Oost 1975: 192. 
of statesmen; and he thought of Pericles as a very progressive and rational leader who was not only a fan of Anaxagoras but saved him from imprisonment. By contrast, he considered Nicias a superstitious man who was gripped by terror at the occurrence of irregular (but still natural) phenomena which he did not quite grasp. This portrayal of Nicias is not evident in Thucydides' work and the reasons will be explained below.

\section{NICIAS AS A RATIONAL PLANNER AND STRATEGIST}

Contrary to Plutarch, Thucydides presents Nicias as an excellent general,

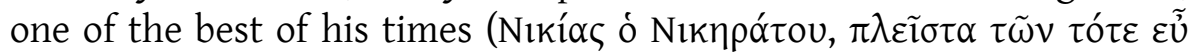

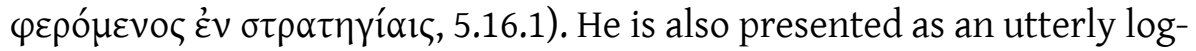
ical planner whose strategic choices were based on calculation and reason. For example, when Nicias delivers his two speeches against the Sicilian Expedition before the Athenian assembly in 415 , he does not once evoke religious omens or the gods. ${ }^{5}$ On the contrary, it is others who turn to prophecies $\left(\theta \varepsilon \varepsilon^{\alpha} \sigma \alpha \nu \tau \varepsilon \varsigma, 8.1\right)$ predicting success for the expedition and it is they who discard Nicias' warnings. Conclusion: if Thucydides wanted to present Nicias as superstitious, he would certainly have attributed to him some religious arguments in his two speeches against the expedition.

In his first speech Nicias makes the following three arguments which are solely based on reason:

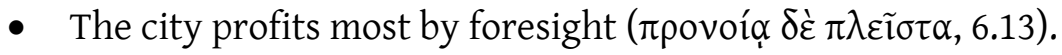

- He says that he wishes to leave as little as possible to chance

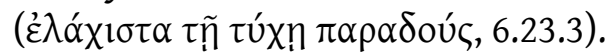

- He claims that decisions ought to be based on hard facts and not on matters that are invisible and lie in the future $(\alpha \varphi \alpha v \tilde{\omega} v \kappa \alpha i$

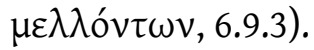

5 N. speaks about the ill-will of the gods in his last speech (7.77-78), and this has been assessed as a theological statement inappropriate to the occasion (Hornblower 2008: 716). But at this point, the Athenians have already been defeated and N. needs to reassure them that the worse is already behind them by giving hope; divine justice is the last tool a general has at his disposal to build morale. 
In his second speech, he likewise uses reason as the foundation for his arguments. By now, he has realised that the people of Athens are keen on the expedition and attempts to dissuade them by presenting his calculations of the huge cost which the supplies will entail. This assessment serves the dual purpose of (hopefully) deterring the Athenians from voting in favour of the expedition, and of providing insurance against failure, in case the expedition is undertaken. The author later shows that these calculations were exact, and that the army was well prepared for a full siege of Syracuse. ${ }^{6}$ It ought to be added that Nicias did not underestimate the force of accident since, in his first speech, he states that an enterprise as far away as Sicily involves risks and dangers which could not be entirely calculated or controlled (6.20).

Coming now to the episodes of the expedition, Nicias and Lamachus remained in charge after the recall of Alcibiades but Thucydides focuses mostly on Nicias. A fact (which many modern historians pass over hastily) is that he planned a very successful siege of Syracuse and was on the verge of taking it by executing a speedy assault and by employing bold tactics of surprise. It is rarely emphasised that the enemy was at the point of capitulation when Gylippus arrived, and that the Syracusans had begun negotiations with Nicias concerning the terms of their surrender (6.104.4). The portrait which Thucydides paints is that of a skilled and experienced general who calculated the situation with precision and who acted with exceptional speed.

That Gylippus and the Corinthians arrived at the exact moment when Syracuse was about to be taken is presented as a fatal coincidence. However, some historians claim that it was Nicias' fault because he failed to foresee the arrival of the enemy, especially since Gylippus' ships had been spied at sea. For example, John H. Finley goes so far as to state that Nicias made "his second although not the last of his famous mistakes" 
when he failed to send a dispatch to intercept the nineteen Peloponnesian ships of Gylippus. ${ }^{7}$ Pace Finley and other historians, a careful examination of Thucydides' text suggests that the situation was uncertain in many respects. How could Nicias have guessed that Gylippus was about to invade the Athenian contingent since Gylippus was himself unsure about which course of action to follow? The author explicitly says that he had given up on Sicily:

Gylippus abandoned all hope of Sicily, and wishing to save Italy, rapidly crossed the Ionian Sea to Tarentum with the Corinthian, Pythen, two Laconian, and two Corinthian vessels, leaving the Corinthians to follow him after manning, in addition to their own ten, two Leucadian and two Ambraciot ships (6.104.1; trans. Crawley)

A key passage follows:

Nicias heard of his [Gylippus'] approach, but, like the Thurians, des-

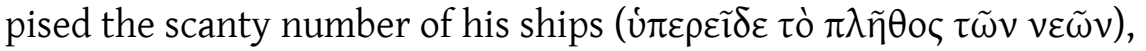
and set down piracy as the only probable object of the voyage, and so took no precautions for the present (6.104. 3; trans. Crawley).

Given the fact that the reader is made aware that Gylippus toured Italy with only a few accompanying vessels and no definite purpose, Nicias' misperception seems justified (why else would Thucydides have provided such detail and why would he have mentioned that the Thurians made the same mistake unless he wanted to explain Nicias' mistake)? Historians have judged the Athenian general from the point of view of the end-result without assessing what information he had at his disposal at the time. It seems preferable to conjecture that Thucydides attributes

7 Finley 1963: 233-34. See also Westlake 1941: 58-65; Edmunds 1975: 117; Kallet 2001: 157-58; Kagan 2009: 199; Gribble 1999: 82; the latter speaks of the timorous prevarication of N. More recently: Tompkins 2017: 100-11; Nichols 2017: 470. Note that many of the above scholars adopt Demosthenes' view that Nicias procrastinated (7.42.3) but this judgment is explicitly attributed to D. by Thuc. both at the beginning and the end of the paragraph and cannot be taken as an objective assessment of the situation by the author. For bibl. see Hornblower 2008: 622-23. 
Nicias' mistake to an accident, namely that just a few ships were reported to him.

In short, Gylippus' appearance was indeed unexpected since he arrived at the exact point of time when the circumvallation wall was almost (but not entirely) complete, and Syracuse was about to be taken. As already mentioned, the author presents the arrival as a bad coincidence:

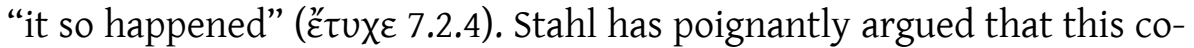
incidence tipped the scales of victor and defeated: had Gylippus arrived just a few days later, Syracuse would have been in the hands of the Athenians. ${ }^{8}$ Thucydides, then, presents Nicias' operation not only as rational

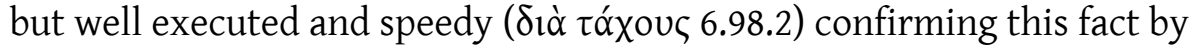
citing Syracusan thoughts: 'they [i. e. the Syracusans] were amazed at the

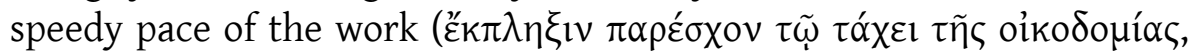
6.98.2). Finally, the historian describes how efficiently the Athenians cutoff the water supplies of the Syracusans and how subsequently the Athenian fleet sailed into the harbour once they felt secure in doing so. Everything had gone as Nicias planned: he had brought the Syracusans very close to utter danger (7.2.4).

The point of the above discussion is to make clear that Thucydidean Nicias is presented as a rational general and tactician and that he has no relation to Plutarch's fearful and superstitious character. Given this, we must consider again what the theiasmos of Nicias consisted in.

\section{THE NUANCES OF $\Theta E I A \Sigma M O \Sigma$ AND MPO $\Sigma$ KEIMENO $\Sigma$}

The exact meaning of theiasmos is difficult to determine. Thomas Hobbes in his 17th-century translation of Thucydides renders it as "superstition" and this meaning is adopted by LSJ, although frenzy is also given as an alternative. ${ }^{9}$ Superstition is clearly a mistake, as was noted already by K.J. Dover in Historical Commentary of Thucydides (although this realisation did not stop the great scholar from labelling Nicias as unenlightened: "an

8 Stahl 2003: 91.

9 Hobbes 1989: 474. 
educated man in such a position [as Nicias] should have paid less attention to the seers"). ${ }^{10}$ Dover adopts Plutarch's opinion of Nicias despite his admission that theiasmos cannot be translated as superstition.

A more common rendition of theiasmos is divination, thus given in the older translations by Richard Crawley and Benjamin Jowett. Likewise, Simon Hornblower translates it as divination in his Commentary on Thucydides:

Nicias, who was rather excessively given to divination and that kind

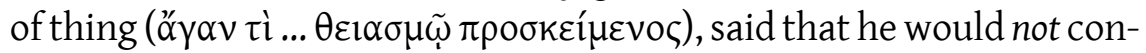
sider moving before the time prescribed by the manteis had passed" $(7.50 .4){ }^{11}$

Slightly different is the Modern Greek translation by the early twentieth century Greek statesman, Eleutherios Venizelos, who translates it as

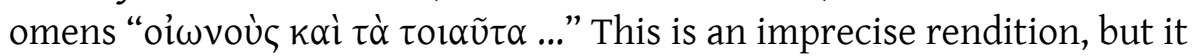
is evocative of the fact that the eclipse was perceived as a bad omen.

The slight variation in the translations illustrates the opaqueness of the nuances of theiasmos and hence the puzzle concerning the nature of the historian's criticism. What exactly was Thucydides annoyed about? After all, divination in battle was a standard practice to which the historian himself must have been subjected many times. ${ }^{12}$

LSJ cites the possibility that theiasmos designates a particular type of prophecy related to frenzy or ecstatic behaviour, but neither meaning is supported by Thucydides' text since it is hard to imagine that the seers in the Athenian army were frantic, or in a state of ecstasy, when they gave their interpretation of the moon eclipse. Finally, Dionysius of Halicarnassus speaks of women prophets who predicted catastrophes. ${ }^{13}$ This gender-specific frenzy cannot possibly apply to the situation in Sicily.

10 Gomme, Andrewes \& Dover 1970: 429.

11 Hornblower 2008: 642.

12 For the examination of the entrails and other portents by seers (as attested in ancient authors) see Burkert 1985: 113; Flower 2008: 154-56. The word theiasmos is not used in this connection.

13 D.H. 7.68. 
The question that needs to be asked next is whether theiasmos is referring to the institution of divination practiced before battle, or if it is just a derogatory name discrediting the habit of practitioners who predicted the future, thus claiming a precise understanding of the divine will. It is proposed here that it is the latter since theiasmos is referred to only once in the text and the participle $\theta \varepsilon 1 \alpha$ ó $\sigma \alpha \nu \tau \varepsilon \zeta$ clearly points to hu-

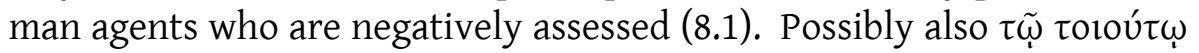
alludes to the seers who shaped the opinion of the army after battle.

Hornblower thinks otherwise, implying that Thucydides' scepticism is applicable to the concept of prophecy in general. He correctly points out to a parallel passage about the plague where prophecies are referred to with contempt: "divinations, and so forth which they used and which

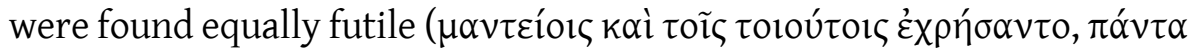
$\grave{\alpha} \nu \omega \varphi \varepsilon \lambda \tilde{\eta} \tilde{\eta} v$ (2.47.2; Crawley modified, italics mine). Hornblower concludes that Thucydides' negative judgment on Nicias, who was excessively given to divination and "that kind of thing," has been "long held back" in the narrative. ${ }^{14}$ However, the sentence which Hornblower cites clearly points to the people who utilised the oracles ( $\dot{x} \propto \rho \dot{\eta} \sigma \alpha \nu \tau o)$ for their own purposes. The subject of $\dot{x} \chi \eta \dot{\sigma} \sigma \alpha \nu \tau o$ is probably the manteis and similar religious practitioners, and it is against them that the criticism of the historian is directed.

There is a further aspect to consider: Nicias was not habitually susceptible to prophecies since when the oracle mongers predicted success in Sicily, he was clearly not on their side. After the disaster, the false pre-

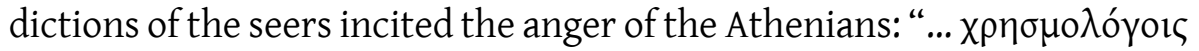

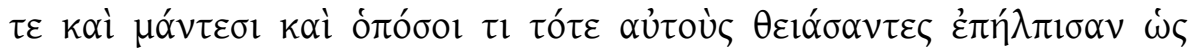

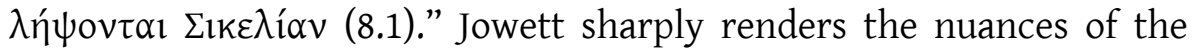
Greek in his translation: "reciters of oracles and soothsayers, and all other omen-mongers of the time (8.1)."

In short, theiasmos does indeed mean divination, or better said, the divine side of a situation, ${ }^{15}$ but the context points also to agency, the seers who interpreted the divine will. If so, Thucydides is saying that $\mathrm{Ni}^{-}$ cias had the inclination to accept whatever the seers suggested, whereas

14 Hornblower 2008: 642.

15 Parker 2000: 299-314. I thank Prof. Parker for his elucidating remarks about theiasmos meaning the divine aspect of a situation in an oral communication. 
he, namely the author (who had also been a general of the Athenian army), felt that it was not the job of the seers to make strategic decisions since this was the role of generals. Note that Plato attempts to correct this impression (perhaps intentionally addressing Thucydides' criticism) in his Laches. There, Nicias is made to say that the soothsayer is obliged

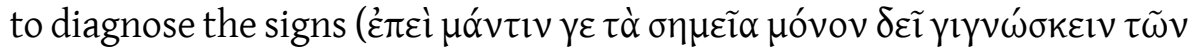
$\dot{\varepsilon} \sigma o \mu \varepsilon ́ v \omega v$,) but someone else (e.g., a general) will need to decide what is the best action-plan (Pl. Laches 195e-196a). ${ }^{16}$ In this manner, Plato rehabilitates the reputation of Nicias' judgment.

Returning now to Thucydides, the case becomes stronger if we con-

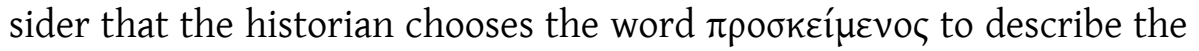
specific attachment of Nicias to theiasmos; because, as it will be argued subsequently, the verb connotes taking sides in an issue or siding with particular persons.

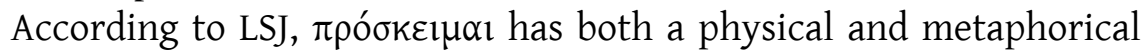
meaning. Literally, it means to be close to an object, as a stone lies next to another stone in a wall, or as when a man is in proximity of a door. In the metaphorical sense, it means devotion or addiction, which is how the verb is often translated in connection with Nicias. And yet, another metaphorical meaning may be more precise: taking the sides of a person, or a group of persons, or even endorsing an idea. Herodotus, for example, writes that he prefers one version of a Scythian legend over others:

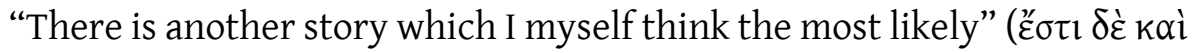

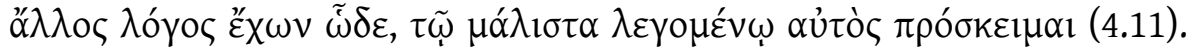
Alternatively, the verb may mean attachment to a particular human being. Again, Herodotus writes that the Spartan king Ariston had a friend

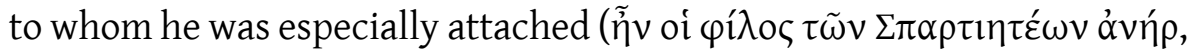

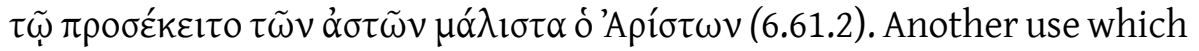

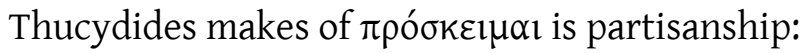

It was for motives of personal ambition that most of them were following ( $\pi \rho \circ \sigma \varepsilon ́ k \varepsilon \downarrow v \tau o)$ this political preference that is most disastrous to oligarchies when they take over from democracies (8.89.3; Warner).

16 In the same dialogue, Nicias makes a distinction between thoughtless fear (the instinctual reaction to danger as experienced by animals or small children) and courage, which entails knowledge (197b). 


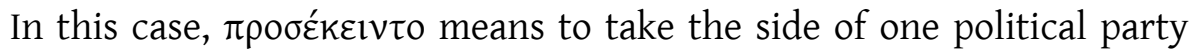
over another, although the author notes that the real motivation was satisfaction of personal ambitions. In another passage, Alcibiades tells the Spartans that he hopes not to be suspected of being politically and

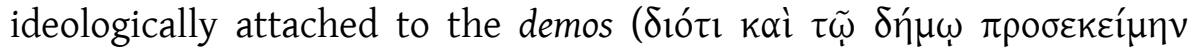
$\mu \tilde{\alpha} \lambda \lambda o v, 6.89 .3)$. Once again, the verb designates a political/ideological preference and attachment to a group, in this case the demos. At another place, Alcibiades is described as being close to Tissaphernes and of doing all he could to gain his favour: "So Alcibiades ... was eagerly flattering

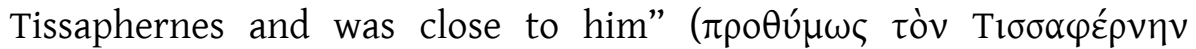
$\theta \varepsilon \rho \alpha \pi \varepsilon u ́ \omega v \pi \rho \circ \sigma \varepsilon ́ \kappa \varepsilon l \tau o, ~ 8.52)$. On another occasion, when Alcibiades was in Sparta, he took the side of the Spartans and their allies against his own people, the Athenians, urging the Spartans to fortify Deceleia and not to

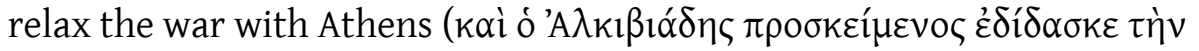

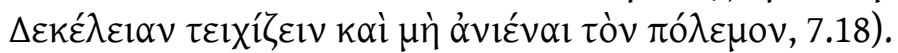

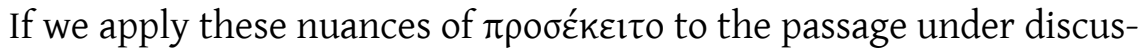
sion, Thucydides is saying that Nicias - perhaps habitually - took the side of the manteis. On his part, the historian shows elsewhere that he had severe reservations about their character and considered them unreliable, self-seeking and capable of promoting their own agenda instead of the common good. Indeed, such people could inflict damage on the democracy. ${ }^{17}$

\section{MANTIS AND GENERAL}

Why might Nicias have taken the side of the manteis? This is an important question, and it will be proposed here that his choice was likely dictated by pragmatism rather than superstition or addiction to prophecy.

The relationship between mantis and general was a sensitive one working best when the two did not disagree but formed a unified front with the purpose of building up the morale of the soldiers. The subject has been thoroughly explored by Michael Flower, who points out that when general and seer disagreed, the morale and indeed mental health

17 Marinatos 1981: 51-52 cf. Thuc. 2.8.2, .21.3; Furley 2006: 415-38. 
of the army could be endangered. ${ }^{18}$ There are even plenty of mythical paradigms in Greek literature reflecting the same, namely they describe the disastrous results that ensued from dissention: consider the conflict between Agamemnon and Calchas in Iliad; Teiresias and Oedipus in Oedipus King; Calchas and Agamemnon in Euripides' Iphigeneia in Aulis. In light of this information, Nicias' decision to side with the seers may have been a rationally based choice with the aim of avoiding mutiny in his army a mutiny which would have proven fatal to their survival. ${ }^{19}$ These pragmatic considerations were surely understood by Thucydides, ${ }^{20}$ even so he seems to have wished that Nicias had, on this occasion at least, intervened more forcefully and had not sided with the manteis. This taking of

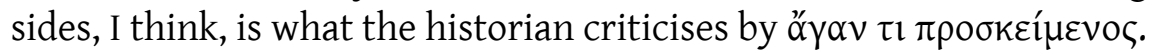

Are we splitting hairs? Does it make much difference if theiasmos points to the agents of divination rather than the concept itself? It does matter, I believe, if our aim is to assess Thucydides' portrait of Nicias. If the historian considered him an irrational man, then he certainly did not appreciate him as a general because military men must be capable of calculating their strategies precisely and soberly. Indeed, Thucydides demonstrates in his narrative that Nicias recognized opportunities and assessed situations correctly during the Archidamian War when he practically had zero failures (5.16.1), ${ }^{21}$ whereas in Sicily he acted prudently taking his time to gather allies and supplies and acted suddenly by landing near Syracuse in darkness and speedily capturing Epipolai. Moreover, the historian shows profound admiration of Nicias in a funerary epigram in which he praises the latter as a man of exceptional arete. This word surely does not solely refer to moral integrity but also military acuity and valour (7.86.5). ${ }^{22}$ True, Nicias' partiality to the manteis was considered a weakness by the historian, but it was a tiny part of his overall positive

18 Flower 2008: 156-58 and 16.

19 Piccirilli 1997: 1-8.

20 Greenwood 2017: 167, reasonably says that the failure of the Sicilian expedition may have been a result of pragmatic decisions.

21 Geske 2005: 177-79.

22 Adkins 1975:379-92; Ossipova 2001:113-18; Steinbock 2017: 109-70. But see Tompkins 2017: $120-2$. 
14 NANNO MARINATOS

presentation: we might call it a mere parenthesis, rather than a judgment long held back, as the authoritative commentator puts it. ${ }^{23}$

23 Hornblower 2008: 642. 


\section{TRANSLATIONS}

Crawley = The Complete Writings of Thucydides: The Peloponnesian War. The unabridged Crawley translation with an introduction by J.H. Finley, Jr. New York 1951.

Hobbes = The Peloponnesian War, Thucydides. The complete Hobbes Translation, ed. D. Grene. Chicago \& London 1989.

Perrin = Plutarch's Lives III, ed. and trans. B. Perrin. London 1916.

Warner $=$ Thucydides the Peloponnesian War. Translated by Rex Warner 1954, revised 1972; introduction and notes M.I. Finley. London \& New York 1970.

\section{BIBLIOGRAPHY}

Adkins, A. 1975. 'The Arete of Nicias: Thucydides 7. 86' GRBS 16, 379-92. Burkert, W. 1985. Greek Religion. Transl. by John Raffan. Oxford. Finley, J. H. 1963. Thucydides. Ann Arbor \& Michigan. Flower, M. 2008. The Seer in Ancient Greece. Berkeley. Furley, D. 2006. 'Thucydides and Religion' in R. Antonios \& A. Tsakmakis (eds.) Brill's Companion to Thucydides, Leiden \& Boston, 415-38.

Geske, N. 2005. Nikias und das Volk von Athen im Archidamischen Krieg. Historia Einzelschriften 186. Stuttgart.

Gomme, A. W., A. Andrewes \& K. J. Dover 1970. A Historical Commentary on Thucydides. Vol. 4. Oxford.

Gribble, D. 1999. Alcibiades and Athens: A Study in Literary Presentation. Oxford.

Greenwood, E. 2017. 'Thucydides on the Sicilian Expedition' in R.K. Balot, S. Fordyce \& E. Foster (eds.) The Oxford Handbook of Thucydides. Oxford, 161-77.

Hornblower, S. 2008. A Commentary on Thucydides. Vol. 3. Oxford. Kagan, D. 2009. Thucydides. The reinvention of History. London.

Kallet, L. 2001. Money and the Corrosion of Power in Thucydides. The Sicilian Expedition and its Aftermath. Berkeley.

Lateiner, D. 1985. 'Nicias' Inadequate Encouragement (Thucydides 7.69.2)' CP 80, 201-13. 
Marinatos N. 1981. Thucydides and Religion. Beiträge zur Klassischen Philologie 129. Königstein.

Nichols, M.P. 2017. 'Leaders and Leadership in Thucydides' History' in R.K. Balot, S. Fordyce \& E. Foster (eds.) The Oxford Handbook of Thucydides. Oxford, 459-74.

Nikolaidis, A.G. 1988. 'Is Plutarch Fair to Nikias?' ICS 13, 319-33.

Nikolaidis, A.G. 1990. 'Thucydides 4. 28. 5 (or Kleon at Sphakteria and Amphipolis)' BICS 97, 89-94.

Oost, S.I. 1975. 'Thucydides and the Irrational: Sundry Passages' CP 52, 186-96.

Ossipova, O. V. 2001. 'Nikias' “Eulogy” in Thucydides (7.86.5) and Greek Epitaphs' VDI 237.2, 113-18.

Parker, R. 2000. 'War and Religion in Ancient Greece', in H. van Wees (ed.) War and Violence. London, 299-314.

Pelling, C.B. R. 1992. 'Plutarch and Thucydides' in P.A. Stadter (ed.) Plutarch and the Historical Tradition. London \& New York, 10-40.

Pelling, C.B.R. 1999. 'How far would they go? Plutarch on Nicias and Thucydides' in Literary Texts and the Greek Historians. London \& New York, 44-60.

Piccirilli, L. 1997. 'Nicia fra astuzie, ricatti e corruzzioni' MH 54, 1-8.

Stahl, H.-P. 2003. Thucydides: Man's Place in History. Swansea.

Steinbock, B. 2017. 'The Contested Memory of Nicias after the Sicilian Expedition' in E. Franchi \& G. Proietti (eds.) Conflict in Communities. Forward-looking Memories in Classical Athens. Collana Quaderni 7. Trento, 109-70.

Tompkins, D. 2017. 'The Death of Nicias: No Laughing Matter' Histos Supplement 6, 99-128.

Westlake, H.D. 1941. 'Nicias in Thucydides' CQ 35, 58-65.

Nanno Marinatos

University of Illinois at Chicago

nannom@uic.edu 